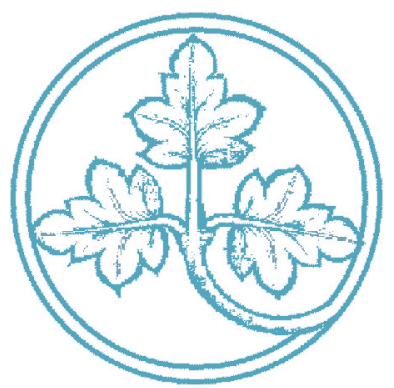

Real Wages and Labour

Productivity in Britain and Germany, 1871-1938:

A Unified Approach to the International Comparison of Living Standards

Stephen Broadberry

Carsten Burhop

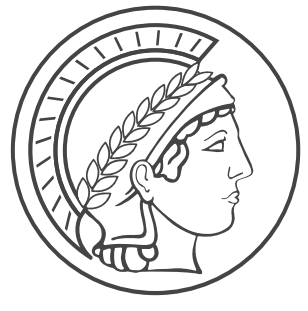




\section{Real Wages and Labour Productivity in Britain and Germany, 1871-1938: A Unified Approach to the International Comparison of Living Standards}

Stephen Broadberry / Carsten Burhop

June 2009 


\title{
Real Wages and Labour Productivity in Britain and Germany, 1871-1938: A Unified Approach to the International Comparison of Living Standards
}

\author{
Stephen Broadberry* / Carsten Burhop ${ }^{\ddagger}$
}

\begin{abstract}
Throughout the period 1871-1938, the average British worker was better off than the average German worker, but there were significant differences between major sectors. For the aggregate economy, the real wage gap was about the same as the labour productivity gap, but again there were important sectoral differences. Compared to their productivity, German industrial workers were poorly paid, whereas German agricultural and service sector employees were overpaid. This affected the competitiveness of the two countries in these sectors. There were also important differences in comparative real wages by skill level, affecting the extent of poverty.
\end{abstract}

JEL Classification: N13, N33, E24

Keywords: Economic history, Britain, Germany, Real wages

Acknowledgements: We would like to thank seminar participants in Bonn, Harvard, Munich, Warwick and Zurich for helpful comments. Carsten Burhop would like to thank the Deutsche Forschungsgemeinschaft for financial support as well as the University of Warwick's Department of Economics for its hospitality.

Department of Economics, University of Warwick, Coventry CV4 7AL, United Kingdom, Email: S.N.Broadberry@warwick.ac.uk

$\$ \quad$ Max-Planck-Institut zur Erforschung von Gemeinschaftsgütern, Kurt-Schumacher-Straße 10, 53113 Bonn, Germany, Email: burhop@coll.mpg.de 


\section{Introduction}

International comparisons of living standards are often conducted using data on labour productivity or GDP per capita, while national debates on living standards are frequently conducted in terms of real wages. Since real wages and labour productivity do not always yield the same picture, there is a need for a unified approach to the international comparison of living standards, which covers both real wages and labour productivity.

Recently, a broad consensus has been reached regarding the comparative performance of the British and German economies during the second half the nineteenth century and the first half of the twentieth century, taking labour productivity as the measure (Broadberry, 2004; Broadberry and Burhop, 2007; 2008; Ritschl, 2008; Fremdling et al., 2007). At the outset, Germany lagged behind in all three main economic sectors - agriculture, industry, and services - but its industrial labour productivity converged towards British levels at the turn of the century and hovered around British levels until World War II (Broadberry, 1997, 1998). In agriculture and services, Germany lagged behind throughout the period. Consequently, economy-wide labour productivity was lower in Germany than in Britain (Broadberry, 1998; 2006). Any remaining disagreements in this area are now relatively minor, and do not affect the qualitative conclusions (Ritschl, 2008; Broadberry and Burhop, 2008).

In a perfectly competitive world, we would expect comparative real wages to reflect comparative labour productivity levels in each sector as well as at the aggregate level. In practice, however, there are good reasons to expect a wedge between real wages and real labour productivity, for at least three reasons (Bentolila and Saint-Paul, 2003). First, if the economies are not fully competitive, differences in the mark-up between the countries and over time can induce varying deviations of wages from marginal productivity. Second, the bargaining power of firms versus workers can also vary between countries and over time. This affects the wage-productivity relation since the wage is a weighted average of the average product of labour and its opportunity costs, with the weight of the former being equal to the workers' bargaining power. ${ }^{1}$ Third, labour adjustment costs can also drive a wedge between the marginal product of labour and the wage, since the marginal costs then includes the wage, the adjustment costs, and the future expected adjustment costs.

The historical literature suggests that these theoretical reasons indeed affected the relationship between wages and labour productivity in Britain and Germany. The impact of cartels on the economic development of Imperial Germany is an evergreen of economic history and these cartels might have led to a higher mark-up in Germany compared to Britain, i.e., to wages below labour productivity (Webb, 1980; Peters, 1989). For example, Allen (1979) showed that in the iron and steel industry, the mark-up and the labour productivity was substantially higher in Germany than in Britain, whereas wages were lower. Moreover, increased bargaining power and

$1 \quad$ See Blachard and Fischer (1989, chapter 9) for a formal model. 
resulting changes in the labour share were a key element in the "Borchardt controversy" about the origins of high unemployment and weak investment in interwar Germany (Borchardt, 1979).

Beyond theoretical reasons, simple measurement differences might result in differences between comparative labour productivity and comparative real wages within sectors. First, real labour productivity is compared using purchasing power parities (PPP) from the output side, whereas real wages are usually compared using expenditure side PPPs. If all goods and services were tradeable without barriers, the two PPPs should be equal. However, if some goods or services are not freely tradeable and if the degree of trade barriers is different for consumers compared to producers, the two PPPs can deviate from each other. Second, the time series of real wages are generated using consumer price indices, whereas the time series of real labour productivity are generated using wholesale price indices or volume indicators. For the same reasons as in the case of PPPs, wholesale and consumer price indices can deviate from each other.

Most of the recent work on comparative living standards in Britain and Germany during the nineteenth and twentieth centuries has been based on income per capita or output per employee, neglecting the functional distribution of income and therefore the comparative level of real wages. By contrast, the evolution of real wages and the functional distribution of income have played a significant role in national debates over the standard of living, as illustrated by a number of controversies. In the British literature, the controversy over the development of real wages during the Industrial Revolution shows little sign of quietening down, while the extent of poverty in the first half of the twentieth century continues to be hotly debated (Feinstein, 1998; Clark, 2005; Allen, 2007; Gazeley and Newell, 2007; Bean and Boyer, 2008). On the other hand, there is no such "standard of living controversy" in Germany and it is generally accepted that German real wages increased substantially during the late nineteenth and early twentieth centuries (Abelshauser, 1982; Wiegand, 1982; Pierenkemper, 1987). Moreover, most authors agree that Germany improved its international competitiveness as a low-wage country, supplemented by technological innovation in a number of science-based industries, including electrical and mechanical engineering as well as chemicals (Allen, 1979; Buchheim, 1983; Labuske and Streb, 2008). In addition, in Germany, there has been a major debate about the loss of competitiveness after World War I and over the extent to which real wages were too high compared to labour productivity (Borchardt, 1979; Holtfrerich, 1984; Ritschl, 1990; Broadberry and Ritschl, 1995). A full understanding of comparative standards of living therefore requires an analysis of both real wages and labour productivity within a unified framework.

This paper provides this unified perspective on comparative living standards by offering an overview of the development of both real wages and labour productivity in Britain and Germany over the period 1871-1938. More specifically, we first calculate benchmarks of the comparative real wages in the two countries by comparing nominal incomes using purchasing power parities (PPPs) from the expenditure side for 1905 and 1937. We then project the comparative real wage of the two countries for the period 1871 to 1938 using national time series of wages and consumer prices. For the economy as a whole, German real wages were around three quarters of the British level during the 1870 s and remained at this level until the early 1890 s, before then con- 
verging to around 83 per cent of the British level by 1913. The Great War and the following period of hyperinflation in Germany had disastrous effects on the comparative real wage position of Germany. German real wages fell back below three quarters of the British level during the first half of the 1920s, and although there was a recovery during the late 1920s, this was quickly followed by the Depression of the 1930s, which hit German workers much more severely than their British counterparts. During the Nazi period, the German real wage recovered to 83 per cent of the British level in 1937, the year of our second benchmark.

Throughout the period 1871-1938, then, the average British worker was substantially better off than the average German worker, but the scale of the British lead varied over time and across sectors. For the aggregate economy, the real wage gap was about the same as the labour productivity gap, but there were substantial differences across the main sectors. Compared to their productivity, German industrial workers were poorly paid, while German service sector workers were very well remunerated. This affected the competitiveness of the two countries in these sectors. In particular, the substantial rise of German industrial unit labour costs, i.e. the ratio between real labour costs and productivity, over the 1913-1925 period was heavily discussed during the Borchardt controversy (Borchardt, 1979; Balderston, 1982; Holtfrerich, 1984; Ritschl, 1990; Broadberry and Ritschl, 1995). Our results confirm Borchardt's finding that comparative unit labour costs indeed increased substantially in Weimar Germany compared to the pre-war period, particularly in industry. However, by considering levels as well as rates of change of both real wages and labour productivity on a comparative basis, we are able to show that German industrial workers were still poorly paid in an international perspective, given their relatively high productivity.

There were also differences in comparative real wages by skill level. Whilst most occupational groups were better paid in Britain, unskilled British industrial workers were as badly paid as their German counterparts before World War I, and this helps to explain the persistence of large pockets of poverty in Europe's highest wage economy at a time of full employment (Booth, 1903; Rowntree, 1902; Gazeley and Newell, 2007; Bean and Boyer, 2008). This changed with the improvement in the position of unskilled workers across World War I, although poverty remained a problem in interwar Britain because of a sharp increase in unemployment (Linsley and Linsley, 1993; Boyer, 2004).

The remaining parts of the paper are organised as follows. In Section II, we present our estimates of the expenditure side PPPs and the resulting benchmark estimates for comparative real wages in 1905 and in 1937. In the following Section III, we discuss the time series used for projection between the benchmarks and present the results of the time series projection for the aggregate economy and the three major sectors. In Section IV, we present evidence on the relationship between comparative real wages and comparative labour productivity for the aggregate economy and at the sectoral level. Section V discusses comparative real wages by occupation and the implications for poverty. The final Section VI concludes the paper. 


\section{Benchmark estimates of comparative real wages \\ 1. Previous studies}

Our benchmark estimates for comparative real wages in 1905 and 1937 combine data from several sources. The main sources for the 1905 benchmark are enquiries of the British Board of Trade about the incomes and expenditures of working class households in Britain and Germany (Board of Trade, 1908a, 1908b). Similar sources have been used to calculate comparative real wage benchmarks for industry by Phelps Brown and Browne (1968: 46, 201) and Williamson (1995: 184, 190). The basic procedure is to compare money wages in the two countries by converting them to a common currency using a purchasing power parity (PPP), obtained by comparing the prices of goods and services in the two countries, weighted by their importance in consumer expenditure. This is necessary because the exchange rate cannot be assumed to be a perfect guide to differences in prices between two countries, particularly when there are non-traded goods and services (Balassa, 1964; Samuelson, 1964).

The main difference between our estimate for 1905 and that of Phelps Brown and Browne (1968) is that they use only the expenditure shares of British households to estimate the PPP, whereas we use the geometric mean of British and German expenditure shares. The German expenditure shares are taken from a comprehensive survey of 852 households conducted in 1907 by Germany's Imperial Statistical Office (Kaiserliches Statistisches Amt, 1909: 20*) and the British expenditure shares are taken from the later detailed study of Prest (1954). In contrast, Williamson (1995: 187), who is interested in the global development of comparative real wages, uses the arithmetic average of the budget shares in seven countries to calculate a global basket of goods. ${ }^{2}$

For his 1927 benchmark, Williamson (1995) employs data from the International Labour Organisation (ILO) and calculates again world-wide consumer expenditure shares. Phelps Brown and Browne (1968) calculate a benchmark for 1931 and also use data from the ILO. These ILO data, however, only compare the cost of living of a typical worker at Ford in Detroit with the cost of living of similar workers in Manchester, Berlin, and Frankfurt. In contrast, our 1937 benchmark relies on national sources for Britain and Germany. For Britain, we employ price data and budget shares from Stone and Rowe (1954), both for 1937. The German data are taken from a 1937 household survey conducted by the Arbeitswissenschaftliches Institut der Deutschen Arbeitsfront (1940). Our reliance on comprehensive official surveys for the two countries should yield more accurate PPPs.

\section{PPPs for 1905 and 1937}

Tables 1 and 2 show the budget items included in our benchmark estimates of expenditure side PPPs, their prices in the two countries, and their budget weights. The first column in both tables gives a description of the item and the second column the unit of measurement. The third and 
fourth columns show the German price in Pfennig and the British price in pence, respectively. The fifth column gives the PPP for each specific product, while the last two columns display the budget shares of each item within the four main categories of food, fuel \& light, alcohol \& tobacco, and rent. The rows showing the four main categories give the PPPs for the sub-categories and the weights for each sub-category in total consumption. ${ }^{3}$

An example from Table 2 might be helpful to illustrate the calculations. In 1937, one pint of beer cost 37.8 Pfennig (7.37 pence at the exchange rate) in Germany and 6.00 pence in Britain, yielding a PPP of $£ 1=R M 15.12$. Since the exchange rate was $£ 1=R M 12.30$, this means that beer was 23 per cent more expensive in Germany than in Britain. Within the category alcohol \& tobacco, beer had an expenditure share of 57.0 per cent in Germany and 54.1 per cent in Britain. The geometric mean of the two is thus 55.5 per cent. Multiplying the three comparative prices of the goods in this category with their respective geometrically weighted budget shares gives the PPP for alcohol \& tobacco of 12.64 in 1937. The overall PPP is then calculated as the weighted sum of the PPPs for the four expenditure categories.

The PPP for 1905 is M 20.62 per $£$, only about one percent higher than the official exchange rate and only slightly below Williamson's (1995: 184) estimate of M 21.05 per £. For 1937, however, our expenditure side PPP is RM 17.19 per $£$, or nearly 40 percent higher than the official exchange rate of RM 12.30 per $£$. This is in line with the findings of Fremdling et al. (2007), who estimated a single deflated output side PPP of RM 18.40 per $£$ in $1935 / 36$ for the manufacturing sector. Williamson (1995: 190) also found an expenditure side PPP of RM 18.08 per $£$ for 1927.

\section{Comparative real wages in 1905 and 1937}

We now use the PPPs from Tables 1 and 2 to convert German money wages for 1905 and 1937 into £s and compare them with money wages in Britain. The German nominal income data are taken from Hoffmann (1965: 492-495). They are based on the income data collected by the compulsory accident insurance, and are provided here for the aggregate economy, the three major sectors, and a number of industrial and service sub-sectors. The British data for 1905 are taken from Feinstein (1990) who gives information about the average annual full employment earnings in 1911 for the major sectors and branches of the economy as well as employment in 1911 in those branches. The benchmark estimate of money earnings in 1905 is obtained from Feinstein's 1911 benchmark, projected to 1905 using the wage index from Feinstein (1990). The British data for 1937 are taken from Feinstein (1995), drawing where necessary on Chapman (1953) for the sectoral breakdown.

Table 3 shows the comparative wage income for Britain and Germany in the two benchmark years. For Germany, money wages for the aggregate economy were M 887 in 1905 and RM

3 It should be noted that although the budget studies include data on the expenditure shares of clothing and several kinds of services, they do not contain any volume information (such as numbers of shirts or cinema tickets) which would be needed for the calculation of PPPs. 
1,850 in 1937. This compares to money wages in Britain of $£ 54.64$ and £126.29 in 1905 and 1937, respectively. Dividing the German money wages by the appropriate PPPs of M 20.62 per $£$ in 1905 and RM 17.19 per $£$ in 1937 and then by the British nominal incomes yields a comparative wage of 78.7 per cent in 1905 and 85.2 per cent in 1937 for a full-time equivalent employed worker.

Looking at the three sectors - agriculture, industry, and services - yields the results that German agricultural workers were comparatively poorly paid in 1905, whereas German service sector employees were comparatively well paid. Comparative wages in industry were about the same as comparative wages in the aggregate economy, although there was some variation across industrial branches, with German workers well remunerated relative to their British counterparts in clothing and printing. The high comparative wages in the German service sector largely reflected pay differentials for civil servants, with employees in the government sector receiving 160.5 percent of the income of British civil servants in 1905. ${ }^{4}$ At 100.8 percent, the ratio was also quite high in transport, a heavily regulated sector, but in distribution it was only 65.0 percent. Thus, the comparatively high wages and salaries in services were mainly caused by generous remuneration of government employees and by employees of state owned enterprises. By 1937, German real wages had increased compared with their British counterparts in industry and especially in services, where real wages were now higher than in Britain. However, comparative Germany/UK real wages had fallen back slightly in agriculture.

\section{Time series projections of comparative real wages}

\section{Data sources}

In this section, we project forwards and backwards from the 1905 benchmark presented in Table 3 , using national real wage indices for the aggregate economy and the three major sectors of agriculture, industry, and services. As with the benchmarks for 1905 and 1937, the German nominal income data for the period 1871-1938 are taken from Hoffmann (1965: 492-495). Wiegand (1982) discusses the quality of the other available nominal income series, and concludes that all reliable data sets use the accident insurance statistics. The classic sources for nominal and real wage data, Kuczynski $(1937 ; 1947)$, are ruled out by more recent research. In particular, Kuczynski's data for the pre-World War I period are based on a small sample of comparatively large firms and his inter-war data are based on standard wage rates, not on actual earnings. Bry (1960) uses Kuczynski's data, whereas Hoffmann (1965), Desai (1968), and Hohls (1995) use comprehensive data from the accident insurance statistics. Therefore, our data are comparable to the

4 In Germany, civil service, transportation, and distribution accounted for $6.2,14.1$, and 32.0 percent (13.3, 16.1, and 36.3 percent) of service sector employment in 1905 (1937), respectively (Hoffmann, 1965: 203206). In the United Kingdom, government, transport \& communications and distribution accounted for 5.1, 18.4 and 28.6 percent $(10.7,23.7,43.5$ percent) of service sector employment in 1911 (1937), respectively (Feinstein, 1972: T129-T131). 
time series employed by Phelps Brown and Browne (1968) who use Desai's (1968) time series. In contrast, Williamson (1995: 171) employs wages for unskilled workers in the building trades.

The British data for the period 1880-1913 are taken from Feinstein (1990), as for the 1905 benchmark. For the years 1871-1879 and 1913-1938, we use Feinstein's (1972) wage index, incorporating the minor adjustments presented in Feinstein (1995). The sectoral breakdown for the period 1920-1938 draws on Chapman (1953) as well as the nominal wage data in Feinstein (1995).

To derive the German real wage index, we deflate the nominal earnings series from Hoffmann (1965) using Desai's (1968) consumer price index for the pre-1913 period and the official cost of living price index of the Statistisches Reichsamt for the period 1924-1938. For the pre-1913 period, we do not use the official price index calculated by the Imperial Statistical Office, since this price index included only food prices. The traditional price index often used by economic historians for the pre-1913 period was calculated by Kuczynski (1945). This index was employed, for example, by Bry (1960), Williamson (1995) and Khoudour-Castéras (2008). Kuczynski's cost of living price index combines food prices and housing rents using a ratio of 3:1. Yet, this weighting scheme is not based on actual consumer expenditures shares. Moreover, only rents for Berlin are included in the index. In contrast, Desai's (1968) cost of living index is based on a weighting scheme from the 1907 household survey of the Imperial Statistical Office and also includes rents for other German cities as well as prices for clothing and heating. ${ }^{5}$ The quality of the official cost of living index for the Nazi period (1933-1938) was recently re-assessed by Steiner (2007). He shows that notwithstanding the price freezes enacted by the Nazi government, the price index reflects the level of the cost of living and its increase over the period 1933-38 very well. However, Steiner speculates that the quality of consumer goods declined substantially during this period. For Britain, the widely accepted consumer price index of Feinstein (1972) is used to deflate the nominal wage series.

\section{Trends in comparative real wages}

The results of the time series projection of comparative Germany/UK real wages shown in Figure 1 are based on the 1905 benchmark. However, it should be noted that the results would not be substantially altered by projecting back from the 1937 benchmark, rather than projecting forward from the 1905 benchmark, since there is a high degree of consistency between the benchmarks and the time series projections. Projecting forwards from the 1905 benchmark yields an estimate of the comparative Germany/UK real wage in 1937 of 83.1 percent, which is very close 
to the benchmark estimate of 85.2 per cent, yielding a discrepancy of just 2.4 percentage points, well within the margins of error in this type of work (Broadberry, 2003). ${ }^{6}$

\section{FIGURE 1: Comparative Germany/UK real wage and per capita income (UK=100)}

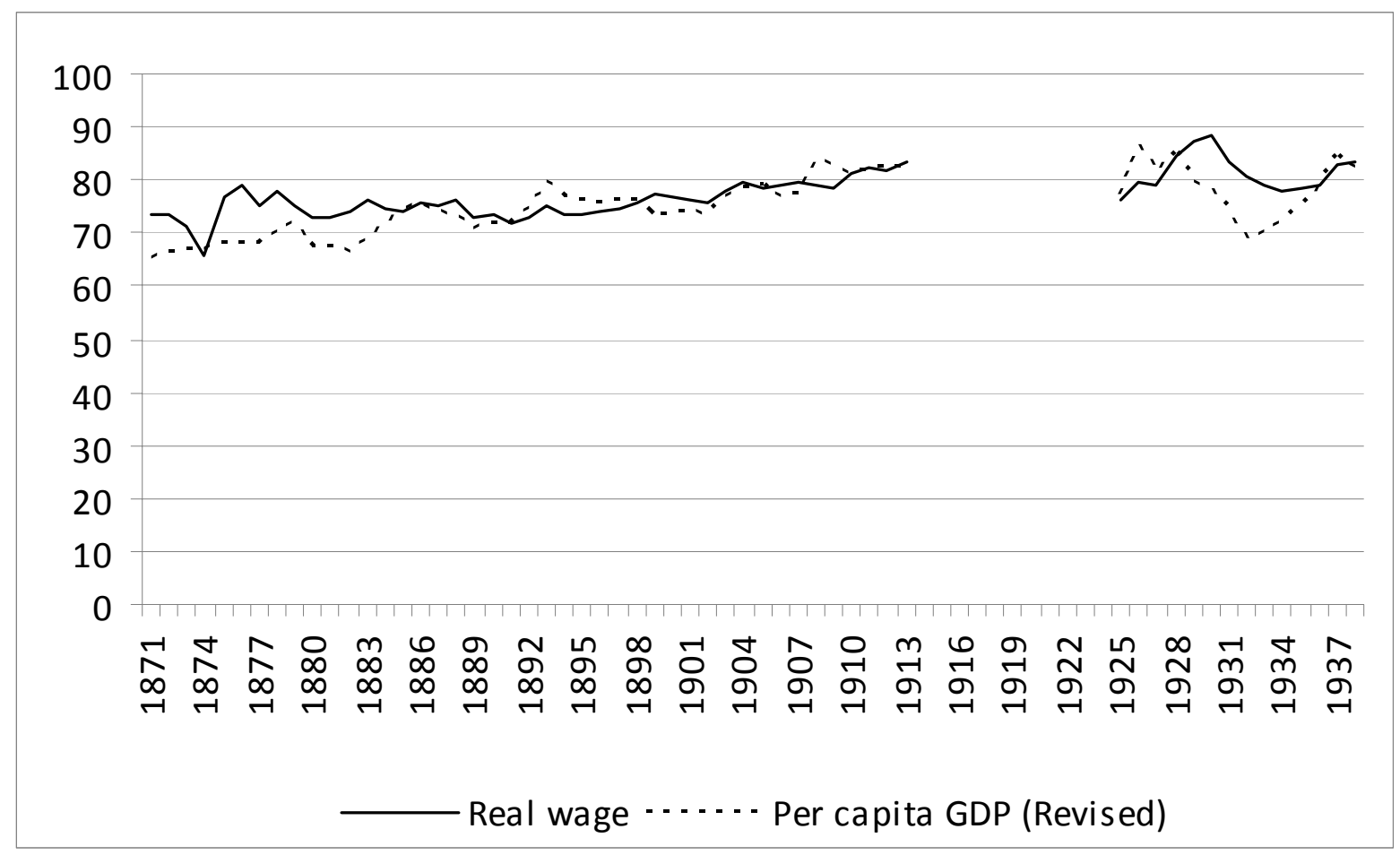

Sources: Comparative real wage: own calculations, see text. Comparative per capita GDP: Maddison (2003), corrected for Burhop and Wolff (2005) and Ritschl and Spoerer (1995) reestimation.

It is helpful to consider the trends in comparative real wages for the aggregate economy in three main periods. First, between 1871 and 1891, there was no tendency for Germany to catch-up on Britain in real wages, although there were significant cyclical fluctuations during this period. In particular, the Gründerkrise of the early 1870s had a sharp negative impact on the living standards of German workers. So also did the tariff on agricultural goods, which had a substantial impact on the cost of living. Between 1871 and 1891, money wages increased by 34 per cent in Germany, but only by 19 per cent in Britain. However, whereas the cost of living fell by 15 per cent in Britain, it remained stable in Germany. It is difficult to avoid the conclusion that these divergent trends in the cost of living were related to the different reactions in Britain and Germany to the possibility of cheap grain imports from the United States (O'Rourke, 1997). For example, the price of bread remained constant in Germany from the early 1870s to World War I, whereas it declined by about one-third in Britain between the early 1870s and the early 1890s and remained constant thereafter (Desai, 1968: 118-119; Mitchell, 1988: 770).

6 It would also be possible to take the geometric mean of the results using the 1905 and 1937 benchmarks. However, since this would make so little difference, we prefer to retain the direct link to the observed data for 1905 . 
Figure 1 also provides data on comparative GDP per capita. Maddison's (2003) data have been modified to take account of the underestimation of capital income in the Hoffmann (1965) NNP series, drawing on the work of Burhop and Wolff (2005) and Ritschl and Spoerer (1995). ${ }^{7}$ Over the period 1871-1938 as a whole, there is broad agreement between comparative living standards measured by both GDP per capita and the real wage. Nevertheless, there are some differences over shorter periods, which require some comment. In contrast to the stagnating comparative real wage between the early 1870 s and the early 1890 s, the trend in Germany/UK comparative GDP per capita was more clearly positive. This can be explained partly by the diverging trends of the price ratio of agricultural and industrial goods in Germany. ${ }^{8}$ Between 1871 and 1891, the price index for agricultural goods increased by about eight percent, whereas the price index for industrial goods decreased by about 26 percent. This led to downward pressure on real wages compared to real GDP per capita since agricultural goods have a higher weight in a consumer price index compared to the national product deflator. Moreover, diverging trends in labour force participation also play a part in explaining the gap between real wages and GDP per capita, since real GDP per capita can be calculated as the product of the real wage per employee and the rate of labour force participation. Thus a high comparative real wage in Germany compared to Britain is consistent with a low comparative real per capita GDP so long as labour force participation is also lower in Germany. Indeed, labour force participation was much higher in Britain than in Germany during the 1870 s and 1880 s, but both countries converged to similar levels over time. More specifically, British labour force participation decreased from 52.9 percent in 1871 to 48.6 percent in 1891, whereas German labour force participation increased from 42.3 percent in 1871 to 45.2 percent in 1891 (Feinstein, 1972: Tables 55 and 57; Hoffmann, 1965: 173-174, 205-206). Therefore, the gap in labour force participation declined from 10.6 percentage points in 1871 to only 2.9 percentage points in 1891 .

Between 1891 and 1913, there was a clear upward trend in the ratio of German to British real wages, from 72.1 percent to 83.3 percent of the British level. Although the cost of living rose more rapidly in Germany than in Britain during this period, money wages increased even more rapidly in Germany compared with Britain. Thus we confirm the hypothesis of a German catchup to Britain during the Edwardian period.

There was a period of disorder between 1913 and 1925, during which German real wages suffered a major setback. We find that the comparative real income position of a German worker in 1925 had fallen back to 76.0 percent of the British level, compared with 83.3 per cent in 1913 . The war and hyperinflation exacted a heavy price from German workers. This was followed by a period of recovery during the second half of the 1920s, with the comparative position of 1913 being restored by 1928. During the 1930s, the Great Depression hit Germany much more se-

7 The NNP per capita series calculated by Burhop and Wolff (2005) for the pre-1913 period and Ritschl and Spoerer (1995) for the interwar period were divided by Hoffmann's (1965) output series and the resulting correction factor was multiplied with Maddison's (2003) estimate of German GDP in 1990 international dollars.

See Jacobs and Richter (1934) for the price indices. 
verely than Britain, leading to a decline of the Germany/UK comparative real wage level, followed by strong recovery during the Nazi period.

\section{Direct and indirect wages}

Khoudour-Castéras (2008) has recently suggested that Bismarck's social legislation had an impact on German emigration before World War I, by providing "indirect wages" which need to be added to the "direct wages" considered so far. The benchmark estimates of comparative real wages in Table 3 and the time series projections in Figures 1 to 3 assume a similar ratio of taxes, social security benefits, unemployment, and working hours in the two countries. To what extent would the calculation of a "total wage", including the indirect wage, change the picture?

In fact, the difference between direct wages and total wages including the net benefits of the social security system would be rather small, simply because workers paid contributions as well as receiving benefits. And to the extent that the costs of the social security system fell partly on firms as well as workers, they depended on distortionary taxation, the effects of which have to be set against any apparent excess of benefits over contributions experienced by workers. The first thing to note is that contributions and benefits were both relatively small for the pre-1914 period, in Germany as well as in Britain. Thus Khoudour-Castéras (2008) claims a ratio of indirect to direct wages in Germany rising from just 2.55 percent in 1885 to 5.85 percent in 1913 . Yet, it is important to note that Khoudour-Castéras (2008) only considered employees covered by the insurance scheme. Thus, the effect on average wages is much smaller since most employees were not covered by the insurance scheme. Indeed, the net transfer of income towards workers using the firms' contributions and taxpayers' money was less than one percent of wages until 1913 (Reuter, 1980). During the interwar period, data published by the Statistisches Reichsamt show that net transfers were on average 3.2 percent of wages between 1925 and $1938 .{ }^{9}$ Thus, redistribution schemes operated on a very small scale until World War II.

In 1913, average social security contributions in Germany were 3.0 and 4.8 percent for blue collar and white collar employees, respectively. In Britain before World War I, the shares of income taxes and national insurance contributions was somewhat lower than in Germany, with people earning less than $£ 160$ per year (around twice the average wage) paying no income tax in 1913 (Mallet, 1913: 484). Social security contributions were introduced in Britain only with the National Insurance Act of 1911, which applied to just 2.3 million largely skilled workers by 1914 (Thane, 1996: 88). Furthermore, rates were low, working out at just 1.89 per cent of income for someone on $£ 150$ per year (Harris, 1972: 380). To the extent that Khoudour-Castéras (2008) finds a significant effect of indirect wages on German emigration between the 1880 s and World War I, it must have operated through a differential impact on those most likely to emigrate, rather than through a large effect on the total wage of the average German worker.

9 Own calculations bases on information given in Statistisches Reichsamt (various issues). Details are available upon request from the authors. 
For the interwar period, the social security system clearly became more important, but again our conclusion is that the net effect of benefits and contributions was small and within the margins of error of international comparative real wage data. In Germany, average social security contributions remained constant across World War I, with blue collar and white collar employees contributing 3.0 and 4.8 percent in 1924 as well as in 1913. Thereafter, social security contributions of both groups increased to about eight percent in 1929, and finally to about nine percent from 1933 (Müller, 1954: 132). In addition, income taxes were substantially higher during the interwar period. Most employees paid no income taxes during the pre-1913 period, whereas the income tax rate for a married worker with two children and average income was about 4.5 percent in 1924 and 2-3 percent from 1925 until 1938. Thus, in Germany, taxes and social security contributions doubled from about five percent in 1913 to about ten percent during the interwar period. ${ }^{10}$ In Britain, those with incomes below $£ 250$ per year in 1937 (again around twice the average wage) paid 2.7 per cent in all direct taxes, including income tax and national insurance contributions (Barna, 1945: 127, 135).

In the absence of an adjustment for the social security system, we need to consider the impact of unemployment, since we are comparing full employment wages. In both countries, unemployment rates were very low during the pre-1914 period. According to Pierenkemper (1987: 58), unemployment averaged about 4.0 percent in Germany between 1900 and 1913. In Britain, average unemployment was 4.4 percent during these years (Feinstein, 1972: T125-T126). ${ }^{11}$ For the interwar period, however, large differences emerged between the two countries. Between 1924 and 1938, the unemployment rate averaged 17.6 percent in Germany, fluctuating strongly (Petzina, 1987: 242). In Britain, average unemployment was much higher than before the war, at 10.1 percent, but substantially lower than in Germany, particularly during the early 1930s (Feinstein, 1972: T125). German workers were therefore more strongly affected by unemployment than British workers during the interwar period. However, to the extent that the social security system provided insurance against unemployment, the comparative welfare effects of this would have been more limited than if the differential unemployment had occurred before World War I.

Turning to hours worked, Huberman and Minns (2007: 548) suggest that Germans worked longer hours than Britons before World War I, but shorter hours between the wars. In the United Kingdom, hours worked declined from 2,755 hours per year in 1870 to 2,656 hours in 1913, and further to 2,200 hours in 1938. The comparable figures for Germany are 3,284 hours in 1870, 2,723 hours in 1913 and 2,187 hours in 1938. According to these figures, German employees worked about 19 per cent more than their British counterparts in 1870, about 2.2 percent more in 1913, but about 1 per cent less in 1938. The 1913 and 1938 figures suggest that accounting for differences in hours worked would have little effect on comparative living standards, but the

10 Scholz (1986: 298-299) calculates average income tax and social security contributions for skilled and unskilled German workers in 1913 and 1924. In 1913 (1924) skilled workers had deductions of 6.2 (10.3) percent, whereas unskilled workers had deductions of 5.0 (9.7) percent. Hachtmann (1988) presents time series of average income tax and social security contributions for the period 1928-1944. He shows that average deductions increased from 11.5 percent in 1928 to 14.0 percent in 1938.

11 Boyer and Hatton (2002), using a larger sample of industries, suggest a slightly higher average rate of 6.2 per cent for these years, but with less volatility. 
scale of the difference is more substantial in 1870 . However, it should be noted that Huberman's (2004) study, on which these estimates for the earlier years are based, does not cover agriculture, which accounted for around half of all employment in Germany, compared with little more than 20 per cent in Britain (Broadberry, 2006: 25). Furthermore, Huberman's study covers very few service occupations, with relatively well treated civil servants being a notable omission.

Jointly and severally, the social security system, unemployment and hours worked are not critical in an assessment of comparative living standards in Britain and Germany for the pre-1914 period. For although German workers did pay higher taxes and social security contributions and worked longer hours before 1914, they also received higher benefits. And more importantly, the magnitudes were relatively small. For the interwar period, although working hours became more similar in both countries, tax rates, social security contributions, and unemployment all became more significant in both countries and impacted more negatively on German workers than their British counterparts. Consequently, our calculations based on the gross earnings of full time equivalent workers may overstate slightly the true welfare of German workers between the wars. However, it is important to bear in mind that it is the net effect of benefits and contributions which matters for the calculation of indirect wages.

\section{REAL WAGES AND LABOUR PRODUCTIVITY BY SECTOR}

\section{Comparative unit labour costs and competitiveness}

So far, we have used the annual time series projections to provide annual estimates of comparative real wages for the economy as a whole. In fact, it is possible to do this at the level of the three main sectors, and the annual data are provided in the Appendix, Table A-1 and charted in Figure 2. The sectoral analysis adds some important additional information to the aggregate picture analysed in Figure 1, showing that German industrial workers received about the same proportion of the British real wage as the average across all sectors, while workers in German agriculture received less and German service sector workers received rather more. Indeed, by the outbreak of World War I, German service sector workers were better paid than their British counterparts, and this remained the case throughout the interwar period.

We now use the sectoral real wage data to analyse the relationship between comparative real wages and comparative labour productivity, deriving comparative unit labour costs in Table 4. This will enable us to address issues of the competitiveness of the German and British economies in the main sectors of the economy. To do this, however, it is necessary to compute comparative own product real wages for each sector, using producer prices rather than the consumer prices used in Tables 3 and A-1. Sectoral wholesale prices indices are taken from Mitchell (1988: 725726) for Britain and Statistisches Reichsamt (1926: 263; 1931: 256; 1939: 363) for Germany. For both countries, the wholesale price index for foodstuffs is used to deflate agricultural wages, the wholesale price index for materials is used to deflate industrial wages, while service sector and total wages are deflated by the overall wholesale price index. Comparative levels in 1905 are 
obtained using PPPs for industry from Broadberry and Burhop (2007) and for agriculture from O'Brien and Prados de la Escosura (1992). The PPP used for services and the aggregate economy is a weighted average of the PPPs for agriculture and industry, using the geometric means of the employment shares in Britain and Germany as weights. The producer price PPPs for 1905 are 19.22 for industry, 21.5 for agriculture and 19.77 for services and the aggregate economy.

\section{FIGURE 2: Comparative Germany/UK real wage by sector $(\mathrm{UK}=100)$}

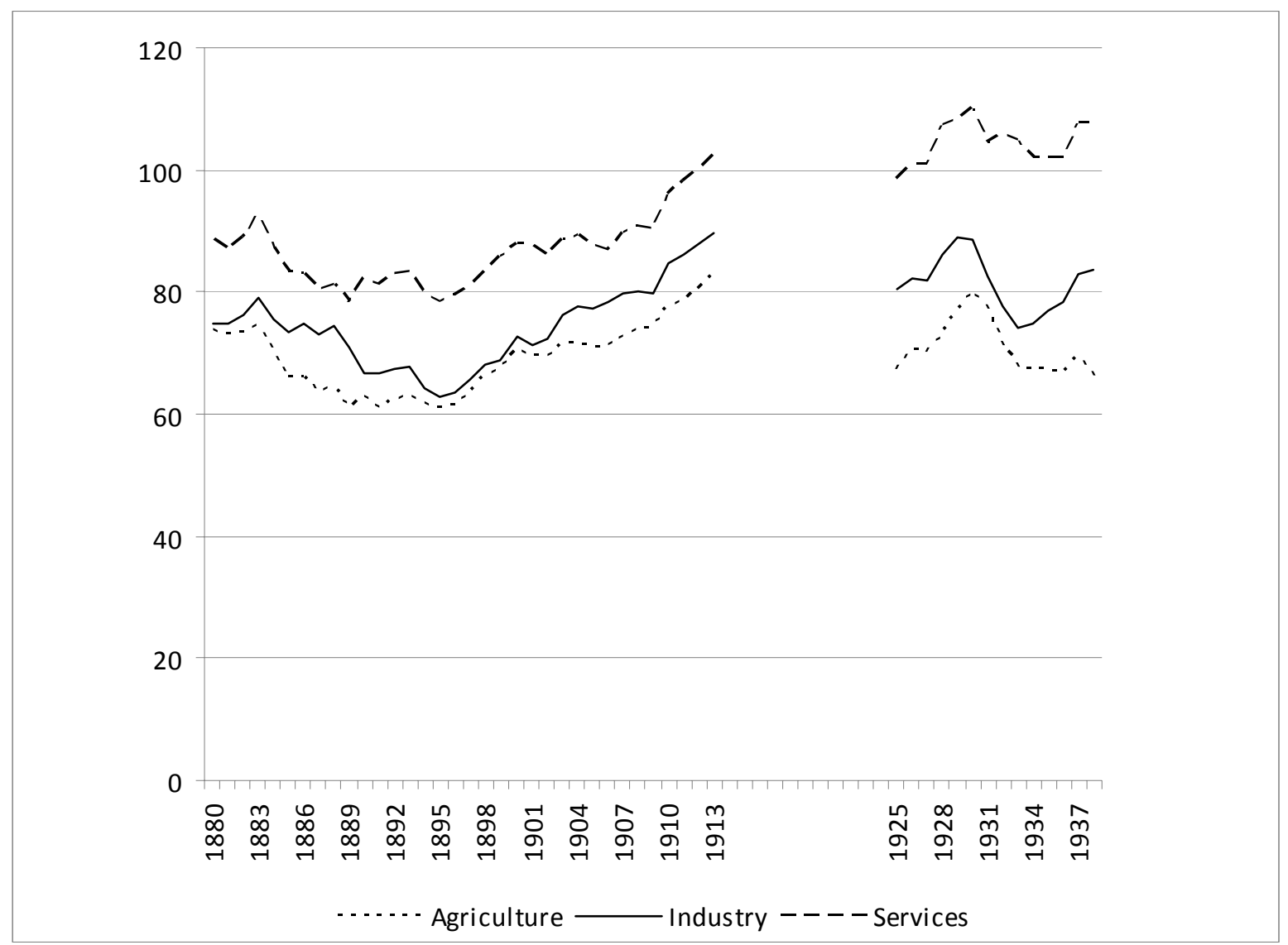

Source; Appendix, Table A-1.

Comparative own product real wages are presented in the first panel of Table 4. Although there are some minor differences from the comparative real wages calculated using consumer prices, the broad pattern of comparative own product real wages is quite similar, with German service sector workers better remunerated than average, German agricultural workers less well remunerated than average, and German industrial workers receiving about the same proportion of the British real wage as the average across all sectors.

The second panel of Table 4 then sets out the data on Germany/UK comparative labour productivity for a number of years between 1881 and 1937, taken from Broadberry (2006). German labour productivity had converged to the British level in industry by the end of the nineteenth century, but Germany's overall labour productivity remained substantially lower because of a substantial productivity gap in agriculture and services. This sectoral pattern of comparative productivity performance persisted across World War I and throughout the interwar period. Combining 
this comparative productivity data with the information on comparative own product real wages yields the data on comparative unit labour costs in the third panel of Table 4. The ratio was around 100 for the aggregate economy in 1891, 1925 and 1937, indicating that over the long run, on average, German workers were remunerated broadly in line with their comparative productivity level.

It is interesting, however, to consider the ratio in the three main sectors. To the extent that comparative real wages were higher than comparative labour productivity, a sector was likely to have difficulty competing internationally. This seems to have been the case - with 1935 being the only exception - for German agriculture throughout the period, which is consistent with what we know about tariffs and high food prices in Germany. For example, Webb (1982) estimates that German consumers subsidised German agricultural producers by about three percent of the annual NNP in 1907. However, it was even more strongly the case for services, where we have already noted the comparatively high levels of remuneration in Germany, as a result of civil service pay levels. The economic effects of this were far reaching, since high service sector wages meant that Germany was internationally uncompetitive in private services, which remained a comparatively small part of the German economy (Broadberry, 2004). Britain, by contrast, had a large, internationally competitive service sector throughout this period. In industry, however, the situation was exactly the opposite of that in services, with German workers poorly paid compared to their labour productivity. This resulted in difficulties for British industry, facing a strong competitive threat from German industry already during the "Made in Germany" scare of the 1890s (Williams, 1896).

\section{Implications for the Borchardt controversy}

Unit labour costs play a central role in the Borchardt controversy. Borchardt (1979) hypothesised that hourly industrial wages were higher in interwar Germany than in pre-war Germany, whereas labour productivity was lower. As a consequence of high unit labour costs, investment was low and unemployment high in Weimar Germany. Thus, high unit labour costs contributed to the downfall of Weimar Germany. Much of the early controversy remained tightly within the confines of Borchardt's framework, using alternative data to dispute the changes in labour productivity or real wages within Germany between 1913 and the 1920s (Holtfrerich, 1984; Ritschl, 1990). Although a number of later contributions placed the debate within an international comparative framework, they continued to focus on rates of change of unit labour costs. Thus Balderston (1982) claimed that the increase of unit labour costs compared to 1913 was lower in Germany than in Britain until 1927, and only became higher during 1928-30, while Broadberry and Ritschl (1995) argue that similar increases in unit labour costs in both Britain and Germany help to explain the failure of both countries to benefit from the catch-up possibilities opened up by rapid US productivity growth.

A major innovation of this paper is to provide for the first time data on comparative levels of unit labour costs, rather than indices of change. A further innovation is that we can distinguish be- 
tween the three major sectors of the economy. These innovations allow us to confirm some aspects of Borchardt's (1979) view, but also to shed new light on the controversy. Thus our data confirm the view that unit labour costs in industry and agriculture grew faster in Germany than in Britain between 1911 and 1925 as well as between 1925 and 1929, but they also show that they declined in the service sector. Yet, it must be remembered that services was the least competitive sector during the pre-war period and it was still uncompetitive during the interwar period, so that shifting labour from agriculture and industry into services contributed to the overall decline of German competitiveness. In addition, the industrial sector experienced only a modest increase of unit labour costs between 1911 and 1925. Furthermore, taking account of levels, it must be emphasised that German industrial unit labour costs were still substantially below British industrial unit labour costs in 1925 and 1929. Hence, although German industry did lose some of the advantage of cheap labour across World War I, it remained a low wage industrial producer compared with Britain.

Figure 3 compares our estimates of comparative Germany/UK real wages in industry with the earlier estimates of other writers. Our estimates are between those of Phelps Brown and Browne (1968) and Williamson (1995). Note that Williamson's (1995) estimates are based only on unskilled wages, and show a somewhat higher comparative Germany/UK real wage, on average. This suggests that unskilled workers were comparatively well remunerated in Germany, an issue which we now investigate in more depth.

FIGURE 3: Comparative Germany/UK real wage in industry $(U K=100)$

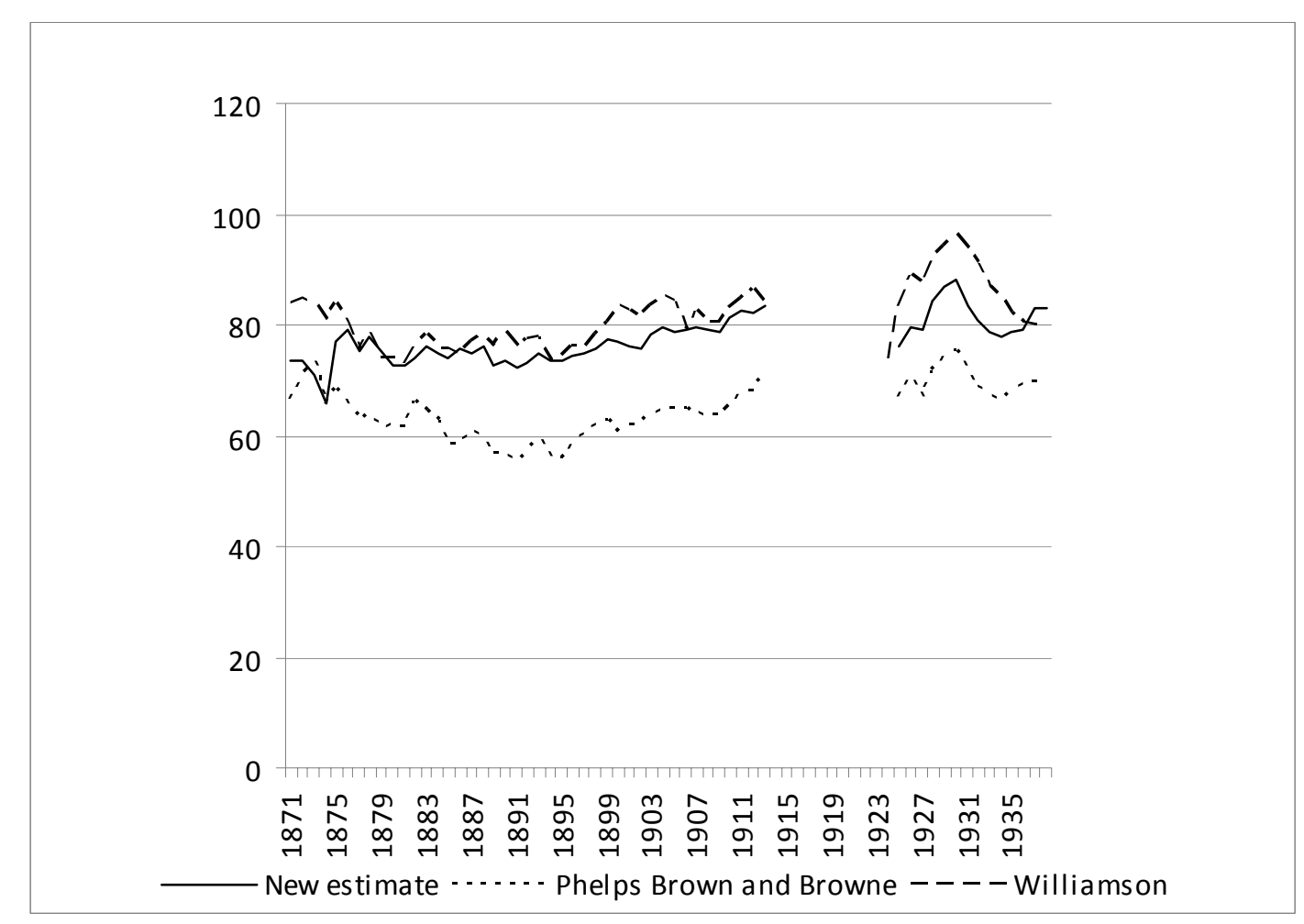

Sources: Appendix, Table A-1; Phelps Brown and Browne (1968); Williamson (1995). 


\section{Comparative real wages by occupation}

The Board of Trade (1908b) conducted an enquiry into wages and the cost of living in Germany in 1905, and made a direct comparison between Britain and Germany in that year. The money wages were converted at the exchange rate and then adjusted for PPP by comparing prices converted at the exchange rate. Table 5 sets out the weekly money wages for a number of industrial trades. It is interesting to note that the ratio of German to British wages was higher amongst the unskilled than amongst the skilled occupations. Indeed, amongst unskilled engineering labourers, the weekly money wage was the same in the two countries. For example, Pierenkemper (1983) provides evidence for a declining skill premium of white-collar employees during the late nineteenth and early twentieth century, while Holtfrerich and Forstmann (1983) present similar evidence for railway employees from the 1850s to the 1870s. Moreover, Scholz (1986: 298-299) shows that average wages of skilled workers declined by 18 percent between 1913 and 1925, whereas average wages of unskilled workers declined by only ten percent.

We now consider the implications of a high skill premium for the existence of poverty in Britain, which became a major political issue in the early twentieth century, following the social surveys of Booth (1903) and Rowntree (1902). Both investigators found around 30 per cent of the working class population living in either primary or secondary poverty at the beginning of the twentieth century. Of course, it must be recognised that the extent of poverty depends on where the poverty line is drawn, but the high rejection rate for recruits during the Boer War suggests that the poor identified by social investigators in the early twentieth century were indeed poor in an absolute sense. Furthermore, Rowntree found low wages to be a major cause of poverty, explaining nearly half of all primary poverty (Boyer, 2004: 301).

Most work on the standard of living is not conducted within an international comparative framework, but once this approach is adopted, the existence of large pockets of absolute poverty in Britain, which was the highest wage economy in Europe at the time, becomes very surprising. If 30 per cent of the British working class lived in such poverty around 1900 that they were unfit for military service, how much worse must the situation have been in Germany, let alone the less developed parts of Europe? Comparative studies on poverty are, however, in short supply. ${ }^{12}$ The only available study investigates pauperism in Britain and Germany in 1885 . It turns out that 6.6 percent of the British population were counted as paupers, whereas only 3.4 percent of the German population belonged to this category (Hennock, 2007: 46-47). The main reason for being poor in Germany during the 1880s was illness or death of the breadwinner, whereas unemployment was comparatively unimportant: only 5 to 10 percent of poverty was related to unemployment, whereas illness accounted for about 45 percent of poverty cases (Frohmann, 2008: 106).

The evidence on comparative wages by occupational groups allows us to reconcile Rowntree's and Booth's findings of high levels of poverty in Britain around 1900 with the fact that Britain was the highest wage economy in Europe at the time. For unskilled workers in Britain were not 
any better remunerated than their German counterparts at this time. Rowntree $(1902 ; 1941)$ identified the causes of primary poverty in York in 1899 and again in 1936, and his findings are reproduced in Table 6, taken from Boyer (2004: 301, 304). In 1899, nearly half of those living in primary poverty were in families where the chief wage earner was in full work but paid low wages. Low wages were similarly implicated in the extent of primary poverty in other pre-World War I social surveys, including Northampton, Warrington, Reading, Stanley and Bolton (Bowley and Burnett-Hurst, 1915; 1920; Bowley and Hogg, 1925). These were the unskilled industrial workers, who were paid no more than their German counterparts, while Davies (1909) painted a similar picture amongst agricultural labourers in Corsley, Wiltshire.

Across World War I, there was a major compression of the skill differential in Britain, with unskilled wages increasing by more than skilled wages (Bowley, 1930: 149; Routh, 1960: 88, 98, 132). ${ }^{13}$ The factors behind this compression have been much debated amongst labour historians, but without reaching a consensus. Possible causes include the minimum wages introduced by the Trade Boards Act of 1909, the spread of the unemployment insurance system, the growing unionisation of unskilled workers and the payment of flat rate increases to offset wartime inflation, as well as changes in technology affecting the demand for particular skills and access to education affecting the supply of skilled workers (Lovell, 1977: 50-55; Bowley, 1930: 148-155; Routh, 135-154; Cole and Postgate, 1987: 504-542). Whatever the reasons for the compression, the effect was to remove one of the main cause of primary poverty in the pre-World War I period. However, this did not have the effect of eliminating poverty in interwar Britain, because of the rise of mass unemployment (Broadberry, 1986; 1990). In Table 6, we see that low wages was the chief cause in just 9.2 per cent of cases of primary poverty in York in 1936, compared with unemployment of the chief wage earner in 44.5 per cent of cases. Unemployment was the main cause of primary poverty in many other interwar social surveys, including Northamption, Warrington, Reading, Stanley and Bolton (Bowley and Hogg, 1925), London (Smith, 1930-1935), Merseyside (Jones, 1934), Southampton (Ford, 1934), Sheffield (Owen, 1933) and Bristol (Tout, 1938).

\section{Conclusion}

This paper provides a comparative perspective on living standards in Britain and Germany over the period 1871-1938, using a unified approach covering both real wages and labour productivity. For the economy as a whole, German real wages were slightly less than three-quarters of the British level in the early 1870s. Between 1871 and 1891, real wages grew at a similar rate in both countries, so that there was no catching-up. After 1891, however, real wages grew more rapidly in Germany, with German real wages converging to around 83 percent of the British level on the eve of World War I. Following the war and postwar hyperinflation, German real wages fell back to about three-quarters of the British level by 1924, and had recovered only to 83 
percent of the British level on the eve of World War II. On average, then, British workers were better off than their German counterparts throughout the period.

For the aggregate economy, comparative real wages were about the same as comparative labour productivity, but there were significant differences across sectors and skill levels. Compared to their productivity, German industrial workers were poorly paid, whereas German workers in agriculture and services were well remunerated. As a result, Germany was highly competitive internationally in industry, but had a comparatively small service sector which was not internationally competitive. Germany's agricultural sector was kept artificially large only through substantial protection. By contrast, Britain's industrial sector had difficulty competing with Germany, but Britain had a very strong position in internationally tradable services. Britain was also reluctant to forego the benefits of free trade in agricultural goods.

There were also important differences in comparative real wages across skill levels. Most occupational groups were substantially better paid in Britain than in Germany, but this did not apply to unskilled workers. Since unskilled workers in Britain received real wages as low as their German counterparts in the pre-World War I period, this helps to explain the persistence of large pockets of poverty in Europe's highest wage economy at a time of full employment. Although unskilled wages rose relative to skilled wages in Britain after World War I, this did not eliminate poverty because of the emergence of the problem of mass unemployment. 
TABLE 1: Expenditure side PPP for 1905

\begin{tabular}{|c|c|c|c|c|c|c|}
\hline \multirow[t]{2}{*}{ Item } & \multirow[t]{2}{*}{ Unit } & \multirow{2}{*}{$\begin{array}{r}\text { Price in } \\
\text { Germany } \\
\text { (Pfennig) }\end{array}$} & \multirow{2}{*}{$\begin{array}{r}\text { Price in } \\
\text { Britain } \\
\text { (Pence) }\end{array}$} & \multirow{2}{*}{$\begin{array}{r}\text { PPP } \\
(\mathrm{M} \text { per } £)\end{array}$} & \multicolumn{2}{|c|}{$\begin{array}{l}\text { German British bas- } \\
\text { basket ket weights }\end{array}$} \\
\hline & & & & & weights (\%) & (\%) \\
\hline Flour & $7 \mathrm{lb}$ & 107.5 & 9.00 & 28.66 & 2.2 & 2.1 \\
\hline Bread & $4 \mathrm{lb}$ & 47.9 & 5.00 & 22.99 & 18.8 & 17.6 \\
\hline Beef & $\mathrm{lb}$ & 70.2 & 6.93 & 24.31 & 16.6 & 11.7 \\
\hline Lamb & $\mathrm{lb}$ & 65.5 & 8.25 & 19.05 & 7.5 & 1.3 \\
\hline Pork \& bacon & $\mathrm{lb}$ & 84.1 & 8.00 & 25.23 & 5.3 & 22.3 \\
\hline Eggs & dozen & 82.8 & 13.91 & 14.29 & 5.4 & 4.2 \\
\hline Milk & quart & 22.4 & 3.50 & 15.36 & 11.5 & 8.5 \\
\hline Butter & $\mathrm{lb}$ & 118.2 & 13.00 & 21.82 & 9.8 & 11.5 \\
\hline Cheese & $\mathrm{lb}$ & 63.8 & 7.00 & 21.87 & 2.8 & 2.3 \\
\hline Margarine & $\mathrm{lb}$ & 70.2 & 7.25 & 23.24 & 1.7 & 4.9 \\
\hline Potatoes & $\mathrm{lb}$ & 22.4 & 3.00 & 17.92 & 5.5 & 5.6 \\
\hline Sugar & $\mathrm{lb}$ & 20.3 & 2.00 & 24.36 & 6.8 & 2.6 \\
\hline Tea & $\mathrm{lb}$ & 231.0 & 18.00 & 30.80 & 0.6 & 4.0 \\
\hline Coffee & $\mathrm{lb}$ & 93.6 & 18.20 & 12.34 & 5.5 & 1.4 \\
\hline FOOD & & & & 21.92 & 55.9 & 56.2 \\
\hline Coal & cwt & 113.9 & 10.75 & 25.43 & 70.6 & 87.0 \\
\hline Kerosene & gallon & 86.2 & 8.86 & 23.35 & 29.4 & 13.0 \\
\hline FUEL \& LIGH & & & & 24.90 & 4.9 & 6.6 \\
\hline Beer & pint & 17.5 & 2.57 & 16.34 & & \\
\hline \multicolumn{2}{|c|}{ ALCOHOL \& TOBACCO } & & & 16.34 & 17.3 & 17.4 \\
\hline \multicolumn{2}{|c|}{$\begin{array}{l}\text { RENT PER ROOM PER } \\
\text { WEEK }\end{array}$} & 140.5 & 16.50 & 20.43 & 21.9 & 19.8 \\
\hline \multicolumn{2}{|l|}{ TOTAL PPP } & & & 20.62 & & \\
\hline
\end{tabular}

Sources: Board of Trade (1908a; 1908b), Kaiserliches Statistisches Amt (1909).

Exchange rate: $\mathrm{M} 20.43$ per $£$. 
TABLE 2: Expenditure side PPP for 1937

\begin{tabular}{|c|c|c|c|c|c|c|}
\hline Item & Unit & $\begin{array}{l}\text { Price in } \\
\text { Germany } \\
\text { (Pfennig) }\end{array}$ & $\begin{array}{r}\text { Price in } \\
\text { Britain } \\
\text { (Pence) }\end{array}$ & $\begin{array}{r}\text { PPP } \\
(\text { RM per } £)\end{array}$ & $\begin{array}{c}\text { German } \\
\text { basket } \\
\text { weights }(\%) \text { wei }\end{array}$ & $\begin{array}{r}\text { British } \\
\text { basket } \\
\text { ghts (\%) }\end{array}$ \\
\hline Flour & $7 \mathrm{lb}$ & 143.3 & 16.00 & 21.50 & 4.1 & 3.6 \\
\hline Bread & $4 \mathrm{lb}$ & 56.6 & 9.50 & 14.30 & 19.0 & 10.1 \\
\hline Beef & $\mathrm{lb}$ & 88.3 & 10.55 & 20.09 & 7.3 & 16.5 \\
\hline Lamb & $\mathrm{lb}$ & 101.3 & 14.15 & 17.18 & 0.4 & 9.0 \\
\hline Pork & $\mathrm{lb}$ & 86.7 & 11.80 & 17.63 & 7.6 & 3.2 \\
\hline Bacon & $\mathrm{lb}$ & 100.5 & 15.20 & 15.87 & 3.6 & 10.2 \\
\hline Eggs & dozen & 126.0 & 24.00 & 12.60 & 3.3 & 8.3 \\
\hline Milk & quart & 26.0 & 6.50 & 9.60 & 15.2 & 14.5 \\
\hline Butter & $\mathrm{lb}$ & 141.7 & 15.20 & 22.37 & 11.1 & 10.1 \\
\hline Cheese & $\mathrm{lb}$ & 42.2 & 10.60 & 9.55 & 3.3 & 2.3 \\
\hline Margarine & $\mathrm{lb}$ & 66.3 & 6.40 & 24.86 & 8.0 & 1.1 \\
\hline Potatoes & $\mathrm{lb}$ & 3.0 & 4.20 & 1.71 & 6.9 & 0.5 \\
\hline Sugar & $\mathrm{lb}$ & 35.7 & 2.50 & 34.27 & 7.0 & 3.5 \\
\hline Tea & $\mathrm{lb}$ & 462.7 & 26.00 & 42.71 & 0.4 & 6.6 \\
\hline Coffee & $\mathrm{lb}$ & 213.2 & 26.30 & 19.46 & 3.0 & 0.7 \\
\hline$F O O D$ & & & & 17.74 & 66.9 & 52.6 \\
\hline Coal & cwt & 161.5 & 27.00 & 14.36 & 27.9 & 58.9 \\
\hline Gas & $1,000 \mathrm{ft}^{3}$ & 567.4 & 42.00 & 32.42 & 32.9 & 23.3 \\
\hline Electricity & $\mathrm{kw} / \mathrm{h}$ & 40.9 & 1.54 & 63.74 & 39.2 & 17.8 \\
\hline FUEL \& LIC & & & & 32.95 & 7.6 & 7.9 \\
\hline Beer & pint & 37.8 & 6.00 & 15.12 & 57.0 & 54.1 \\
\hline Cigarettes & ten & 22.1 & 4.99 & 10.63 & 20.3 & 37.2 \\
\hline Tobacco & ounze & 26.7 & 9.36 & 6.85 & 26.7 & 8.7 \\
\hline \multicolumn{2}{|c|}{ ALCOHOL \& TOBACCO } & & & 12.64 & 5.9 & 19.6 \\
\hline \multicolumn{2}{|c|}{$\begin{array}{l}\text { RENT PER ROOM PER } \\
\text { WEEK }\end{array}$} & 169.3 & 33.08 & 12.28 & 19.6 & 19.9 \\
\hline \multicolumn{2}{|c|}{ TOTAL PPP } & & & 17.19 & & \\
\hline
\end{tabular}

Sources: Prest (1954), Stone and Rowe (1954), Arbeitswissenschaftliches Institut der Deutschen Arbeitsfront (1940). Exchange rate: RM 12.30 per $£$. 
TABLE 3: BENCHMARK ESTIMATES OF COMPARATIVE WAGES

\begin{tabular}{|c|c|c|c|c|c|c|}
\hline & $\begin{array}{l}\text { German } \\
\text { nominal } \\
\text { wage } \\
\text { (Marks) }\end{array}$ & $\begin{array}{l}\text { British } \\
\text { nominal } \\
\text { wage }(£)\end{array}$ & $\begin{array}{l}\text { German wage } \\
\text { as \% of Brit- } \\
\text { ish wage at } \\
\text { PPP } \\
(£ 1=M 20.62)\end{array}$ & $\begin{array}{l}\text { German } \\
\text { nominal } \\
\text { wage } \\
(\mathrm{RM})\end{array}$ & $\begin{array}{l}\text { British } \\
\text { nominal } \\
\text { wage }(£)\end{array}$ & $\begin{array}{l}\text { German wage } \\
\text { as \% of British } \\
\text { wage at PPP } \\
\text { (£1=RM17.19) }\end{array}$ \\
\hline & & 1905 & & & 1937 & \\
\hline Agriculture & 551 & 37.64 & 71.0 & 1,030 & 86.32 & 69.4 \\
\hline Industry & 981 & 61.45 & 77.4 & 1,871 & 131.23 & 82.9 \\
\hline Mining & 1,205 & 74.02 & 79.0 & 2,433 & 158.38 & 89.4 \\
\hline Construction & 1,143 & 71.58 & 77.4 & 1,905 & 146.86 & 75.5 \\
\hline $\begin{array}{l}\text { Engineering \& } \\
\text { shipbuilding }\end{array}$ & 1,113 & 94.54 & 76.4 & 2,245 & 140.1 & 93.2 \\
\hline Iron \& steel & 1,232 & 85.18 & 70.1 & 2,312 & 161.93 & 83.1 \\
\hline Textiles & 637 & 43.86 & 70.4 & 1,278 & 90.93 & 81.8 \\
\hline Clothing & 790 & 37.26 & 102.8 & 1,344 & 97.12 & 80.5 \\
\hline Printing & 1,273 & 61.99 & 99.6 & 2,577 & 139.52 & 107.4 \\
\hline Furniture & 1,005 & 66.17 & 73.7 & 1,612 & 122.61 & 76.5 \\
\hline $\begin{array}{l}\text { Services (without } \\
\text { military) }\end{array}$ & 1,106 & 61.35 & 87.4 & 2,356 & 127.46 & 107.5 \\
\hline Transport & 1,212 & 58.31 & 100.8 & 2,359 & 176.01 & 78.0 \\
\hline Distribution & 853 & 63.64 & 65.0 & 1,631 & 126.56 & 75.0 \\
\hline Government & 2,133 & 64.47 & 160.5 & 3,690 & 129.06 & 166.3 \\
\hline $\begin{array}{l}\text { Aggregate eco- } \\
\text { nomy }\end{array}$ & 887 & 54.64 & 78.7 & 1,850 & 126.29 & 85.2 \\
\hline
\end{tabular}

Sources: Wage data from Feinstein (1972, 1990); Chapman (1953); Hoffmann (1965). PPPs from Tables 1 and 2. 
TABLE 4: Germany/UK comparative unit labour costs

A. Comparative own product real wage

\begin{tabular}{rrrrr}
\hline & Agriculture & Industry & Services & $\begin{array}{c}\text { Aggregate } \\
\text { Economy }\end{array}$ \\
\hline 1881 & 68.5 & 74.8 & 82.4 & 71.4 \\
1891 & 54.7 & 65.2 & 74.0 & 61.5 \\
1901 & 69.4 & 69.1 & 90.2 & 77.0 \\
1911 & 71.5 & 95.0 & 100.1 & 89.1 \\
1925 & 65.3 & 72.5 & 91.3 & 72.9 \\
1929 & 75.7 & 82.5 & 101.6 & 84.1 \\
1935 & 53.3 & 70.8 & 85.9 & 67.5 \\
1937 & 62.0 & 83.9 & 99.9 & 79.4 \\
\hline
\end{tabular}

B. Comparative labour productivity

\begin{tabular}{rrrrr}
\hline & Agriculture & Industry & Services & $\begin{array}{c}\text { Aggregate } \\
\text { Economy }\end{array}$ \\
\hline 1881 & 54.7 & 93.7 & 61.3 & 57.3 \\
1891 & 53.7 & 99.3 & 64.4 & 60.5 \\
1901 & 67.2 & 105.0 & 71.9 & 68.4 \\
1911 & 67.3 & 127.7 & 73.4 & 75.5 \\
1925 & 53.8 & 92.3 & 76.5 & 69.0 \\
1929 & 56.9 & 97.1 & 82.3 & 74.1 \\
1935 & 57.2 & 99.1 & 85.7 & 75.7 \\
1937 & 59.0 & 96.9 & 89.4 & 79.2 \\
\hline
\end{tabular}

C. Comparative unit labour costs

\begin{tabular}{rrrrr}
\hline & Agriculture & Industry & Services & $\begin{array}{r}\text { Aggregate } \\
\text { Economy }\end{array}$ \\
\hline 1881 & 125.1 & 79.8 & 134.5 & 124.6 \\
1891 & 101.9 & 65.7 & 114.8 & 101.7 \\
1901 & 103.3 & 65.8 & 125.5 & 112.6 \\
1911 & 106.3 & 74.4 & 136.4 & 118.0 \\
1925 & 121.4 & 78.5 & 119.4 & 105.7 \\
1929 & 133.1 & 84.9 & 123.4 & 113.5 \\
1935 & 93.1 & 71.5 & 100.3 & 89.2 \\
1937 & 105.2 & 86.5 & 111.7 & 100.3 \\
\hline
\end{tabular}

Sources and notes: Comparative own product real wage: see text; Comparative labour productivity from Broadberry (2006: 21); Comparative unit labour costs derived as the ratio of comparative own product real wage to comparative labour productivity. 
TABLE 5: Predominant weekly money wages in British and German Industry, 1905

\begin{tabular}{|c|c|c|c|}
\hline & $\begin{array}{c}\text { German wage con- } \\
\text { verterd at ex- } \\
\text { change rate } \\
\text { (s./d.) }\end{array}$ & $\begin{array}{l}\text { British wage } \\
\text { (s./d.) }\end{array}$ & $\begin{array}{r}\text { Ratio of mean } \\
\text { predominant wage } \\
(\text { Britain }=100)\end{array}$ \\
\hline \multicolumn{4}{|l|}{ Building trades } \\
\hline Bricklayers & $\begin{array}{c}\text { 26s. } 11 \mathrm{~d} . \text { to } 31 \mathrm{~s} . \\
3 \mathrm{~d} .\end{array}$ & $\begin{array}{l}37 \mathrm{~s} .6 \mathrm{~d} . \text { to } 40 \mathrm{~s} . \\
6 \mathrm{~d} .\end{array}$ & 75 \\
\hline Masons & $\begin{array}{c}\text { 26s. } 11 \mathrm{~d} . \text { to } 31 \mathrm{~s} . \\
3 \mathrm{~d} .\end{array}$ & $\begin{array}{l}37 \mathrm{~s} .2 \text { d. to } 39 \mathrm{~s} . \\
4 \mathrm{~d} .\end{array}$ & 75 \\
\hline Carpenters & $\begin{array}{c}\text { 26s. } 11 \mathrm{~d} \text {. to } 31 \mathrm{~s} . \\
3 \mathrm{~d} .\end{array}$ & $\begin{array}{l}36 \mathrm{~s} .2 \mathrm{~d} . \text { to } 39 \mathrm{~s} . \\
4 \mathrm{~d} .\end{array}$ & 77 \\
\hline Plumbers & 24 s. to 28 s. $6 \mathrm{~d}$. & $\begin{array}{l}\text { 35s. 4d. to 39s. } \\
9 \text { d. }\end{array}$ & 70 \\
\hline Painters & 24 s. to 29 s. $8 d$ & $\begin{array}{l}31 \mathrm{~s} .6 \mathrm{~d} . \text { to } 37 \mathrm{~s} . \\
6 \mathrm{~d} .\end{array}$ & 78 \\
\hline $\begin{array}{l}\text { Labourers } \\
\text { Engineering trades }\end{array}$ & 19s. 6 d. to $24 \mathrm{~s}$. & 23s. 6 d. to $27 \mathrm{~s}$. & 86 \\
\hline Fitters & 26s. to $32 \mathrm{~s}$. & $32 \mathrm{~s}$. to $36 \mathrm{~s}$. & 85 \\
\hline Turners & $27 \mathrm{~s}$. to $33 \mathrm{~s}$. & $32 \mathrm{~s}$. to $36 \mathrm{~s}$. & 88 \\
\hline Smiths & $28 \mathrm{~s} .6 \mathrm{~d}$. to $33 \mathrm{~s}$. & $32 \mathrm{~s}$. to $36 \mathrm{~s}$. & 90 \\
\hline Patternmakers & 25s. $6 \mathrm{~d}$. to $35 \mathrm{~s}$. & $34 \mathrm{~s}$. to $38 \mathrm{~s}$. & 77 \\
\hline $\begin{array}{l}\text { Labourers } \\
\text { Printing trade }\end{array}$ & 18s. to $22 \mathrm{~s}$. & $18 \mathrm{~s}$. to $22 \mathrm{~s}$. & 100 \\
\hline Compositors & $\begin{array}{l}\text { 24s. } 9 \mathrm{~d} \text {. to } 25 \mathrm{~s} . \\
11 \mathrm{~d} .\end{array}$ & $28 \mathrm{~s}$. to $33 \mathrm{~s}$. & 83 \\
\hline $\begin{array}{l}\text { All the above } \\
\text { trades (average) }\end{array}$ & & & 83 \\
\hline
\end{tabular}

Source: Board of Trade (1908b: xlix).

TABLE 6: Causes of primary poverty in Britain (\%)

\begin{tabular}{lrr}
\hline & York & York \\
& 1899 & 1936 \\
\hline Chief wage earner: & & \\
$\quad$ dead or absent & 27.5 & 9.0 \\
ill or old & 10.0 & 23.5 \\
$\quad$ out of work & 2.6 & 44.5 \\
Irregularly employed & 3.5 & 5.9 \\
In full work but: & & \\
$\quad$ low wages & 43.7 & 9.2 \\
$\quad$ more than 3 children & 12.8 & 8.0 \\
\hline
\end{tabular}

Sources: Boyer (2004: 301, 304), derived from Rowntree (1902; 1941). 


\section{APPENDIX: TIME SERIES OF GERMAN-BRITISH COMPARATIVE REAL WAGES, 1871-1938 (UK=100).}

TABLE A-1: Germany/UK comparative real wages, 1871-1938

\begin{tabular}{ccccc}
\hline Year & Agriculture & Industry & Services & $\begin{array}{c}\text { Aggregate Eco- } \\
\text { nomy }\end{array}$ \\
\hline 1871 & & & & 73.4 \\
1872 & & & & 73.6 \\
1873 & & & & 71.2 \\
1874 & & & & 65.9 \\
1875 & & & & 76.8 \\
1876 & & & & 79.1 \\
1877 & & & & 75.4 \\
1878 & & & & 78.0 \\
1879 & & & 88.7 & 75.3 \\
1880 & 73.8 & 74.9 & 86.7 & 72.8 \\
1881 & 72.9 & 74.8 & 92.8 & 72.9 \\
1882 & 73.4 & 76.1 & 87.2 & 76.9 \\
1883 & 74.4 & 79.1 & 83.4 & 74.7 \\
1884 & 69.8 & 75.5 & 82.9 & 73.9 \\
1885 & 65.8 & 73.4 & 80.4 & 75.5 \\
1886 & 66.1 & 75.0 & 81.3 & 74.9 \\
1887 & 64.0 & 73.0 & 78.3 & 76.3 \\
1888 & 64.2 & 74.6 & 82.2 & 72.7 \\
1889 & 61.2 & 70.8 & 81.1 & 73.5 \\
1890 & 62.7 & 66.7 & 83.0 & 72.1 \\
1891 & 61.2 & 66.8 & 83.5 & 73.1 \\
1892 & 62.5 & 67.4 & & 74.9 \\
1893 & 63.0 & 67.6 & & 73.4 \\
1894 & 61.7 & 64.3 & & 74.4 \\
1895 & 61.1 & 62.8 & & 74.9 \\
1896 & 61.4 & 63.5 & & \\
1897 & 63.4 & 65.5 & & \\
1898 & 66.5 & 68.1 & & \\
1899 & 67.4 & 68.9 & & \\
1900 & 70.6 & 72.7 & & \\
\hline & & & & \\
\hline
\end{tabular}


TABLE A-1: Germany/UK comparative real wages, 1871-1938 (continued)

\begin{tabular}{|c|c|c|c|c|}
\hline Year & Agriculture & Industry & Services & $\begin{array}{c}\text { Aggregate Eco- } \\
\text { nomy }\end{array}$ \\
\hline 1901 & 69.5 & 71.3 & 87.6 & 76.1 \\
\hline 1902 & 69.4 & 72.3 & 86.0 & 75.7 \\
\hline 1903 & 71.5 & 76.1 & 88.7 & 78.1 \\
\hline 1904 & 71.7 & 77.6 & 89.2 & 79.5 \\
\hline 1905 & 71.0 & 77.4 & 87.4 & 78.7 \\
\hline 1906 & 71.2 & 78.3 & 86.9 & 79.2 \\
\hline 1907 & 72.7 & 79.7 & 89.6 & 79.7 \\
\hline 1908 & 73.8 & 80.1 & 90.6 & 79.0 \\
\hline 1909 & 74.5 & 79.8 & 90.3 & 78.5 \\
\hline 1910 & 77.6 & 84.7 & 95.8 & 81.2 \\
\hline 1911 & 78.9 & 85.9 & 98.3 & 82.5 \\
\hline 1912 & 80.6 & 88.0 & 99.9 & 82.0 \\
\hline 1913 & 82.8 & 89.6 & 102.3 & 83.3 \\
\hline 1925 & 67.3 & 80.6 & 98.5 & 76.0 \\
\hline 1926 & 70.8 & 82.2 & 100.8 & 79.4 \\
\hline 1927 & 70.2 & 81.9 & 100.8 & 79.1 \\
\hline 1928 & 72.9 & 86.1 & 107.2 & 84.3 \\
\hline 1929 & 76.8 & 89.1 & 108.2 & 87.1 \\
\hline 1930 & 80.1 & 88.6 & 110.0 & 88.3 \\
\hline 1931 & 77.4 & 82.5 & 104.5 & 83.5 \\
\hline 1932 & 71.2 & 77.5 & 105.8 & 80.8 \\
\hline 1933 & 67.7 & 74.2 & 105.0 & 78.8 \\
\hline 1934 & 67.2 & 75.0 & 101.9 & 77.8 \\
\hline 1935 & 67.3 & 77.0 & 102.0 & 78.7 \\
\hline 1936 & 66.8 & 78.4 & 102.2 & 79.1 \\
\hline 1937 & 69.4 & 82.9 & 107.5 & 83.1 \\
\hline 1938 & 66.5 & 83.6 & 107.8 & 83.2 \\
\hline
\end{tabular}

Sources: See text. 


\section{References}

Abelshauser, W. (1982), "Lebensstandard im Industrialisierungsprozeß: Britische Debatte und deutsche Verhältnisse", Scripta Mercaturae, 16, 71-92.

Allen, R.C. (1979), “International Competition in Iron and Steel, 1850-1913”, Journal of Economic History, 39, 911-937.

Allen, R.C. (2007), "Pessimism Preserved: Real Wages in the British Industrial Revolution", Oxford University Department of Economics Working Paper 314.

Arbeitswissenschaftliches Institut der Deutschen Arbeitsfront (1940), Beiträge zur Statistik der Lebenshaltung des deutschen Arbeiters. Vorläufige Teilergebnisse einer Erhebung von Wirtschaftsrechnungen in Arbeiterhaushalten, Berlin: Verlag der Deutschen Arbeitsfront.

Balassa, B. (1964), “The Purchasing-Power Parity Doctrine: A Reappraisal”, Journal of Political Economy, 76, 584-96.

Balderston, T. (1982) “The Origins of Economic Instability in Germany 1924-1930: Market Forces versus Economic Policy", Vierteljahrschrift für Sozial- und Wirtschaftsgeschichte, $69,488-514$.

Barna, T. (1945), Redistribution of Incomes through Public Finance in 1937, Oxford: Clarendon Press.

Bean, J.S. and Boyer, G. (2008), "The Trade Boards Act of 1909 and the Alleviation of Household Poverty", Sixth World Congress of Cliometrics, Edinburgh.

Bentolila, S. and Saint-Paul, G. (2003), "Explaining Movements in the Labor Share", Contributions to Macroeconomics, 3 (1), Article 9.

Blanchard, O. and Fischer, S. (1989), Lectures on Macroeconomics, Cambridge, Mass.: MIT Press.

Board of Trade (1908a), Report of an Enquiry by the Board of Trade into Working Class Rents, Housing and Retail Prices together with the Standard Rates of Wages Prevailing in Certain Occupations in the Principal Industrial Towns of the United Kingdom, (Cd 3864), London: HMSO.

Board of Trade (1908b), Report of an Enquiry by the Board of Trade into Working Class Rents, Housing and Retail Prices together with the Standard Rates of Wages Prevailing in Certain Occupations in the Principal Industrial Towns of the German Empire, (Cd. 4032), London: HMSO.

Booth, C. (1903), Life and Labour of the People in London, London: Macmillan. 
Borchardt, K. (1979), "Zwangslagen und Handlungspielräume in der große Wirtschaftskrise der frühen dreißiger Jahre", Jahrbuch der Bayerischen Akademie der Wissenschaften, 85-132.

Bowley, A.L. (1930), Some Economic Consequences of the Great War, London: Thornton Butterworth.

Bowley, A.L. and Burnett-Hurst, A.R. (1915), Livelihood and Poverty: A Study in the Economic Conditions of Working-class Households in Northamption, Warrington, Stanley and Reading, London: Bell.

Bowley, A.L. and Burnett-Hurst, A.R. (1920), Economic Conditions of Working-class Households in Bolton, 1914: Supplementary Chapter to ,Livelihood and Poverty', London: Bell.

Bowley, A.L. and Hogg, M.H. (1925), Has Poverty Diminished? A Sequel to Livelihood and Poverty, London: King.

Boyer, G.R. (2004), "Living Standards, 1860-1939”, in Floud, R. and Johnson, P. (eds.), The Cambridge Economic History of Modern Britain, Volume II: Economic Maturity, 18601939, Cambridge: Cambridge University Press, 280-313.

Boyer, G.R. and Hatton, T.J. (2002), "New Estimates of British Unemployment, 1870-1913”, Journal of Economic History, 62, 643-675.

Broadberry, S.N. (1986), The British Economy Between the Wars: A Macroeconomic Survey, Oxford: Blackwell.

Broadberry, S.N. (1990), “The Emergence of Mass Unemployment: Explaining Macroeconomic Trends in Britain during the Trans-World War I Period", Economic History Review, 43, 271-282.

Broadberry, S.N. (1997), The Productivity Race: British Manufacturing in International Perspective, 1850-1990, Cambridge: Cambridge University Press.

Broadberry, S.N. (1998), "How did the United States and Germany Overtake Britain? A Sectoral Analysis of Comparative Productivity Levels, 1870-1990”, Journal of Economic History, $58,375-407$.

Broadberry, S.N. (2003), "Relative per capita Income Levels in the United Kingdom and the United States since 1870: Reconciling Time-Series Projections and Direct Benchmark Estimates", Journal of Economic History, 63, 852-863.

Broadberry, S.N. (2004), "Explaining Anglo-German Productivity Differences in Services Since 1870”, European Review of Economic History, 8, 229-262.

Broadberry, S.N. (2006), Market Services and the Productivity Race, 1850-2000: British Performance in International Perspective, Cambridge: Cambridge University Press. 
Broadberry, S.N. and Burhop, C. (2007), "Comparative Productivity in British and German Manufacturing before World War II: Reconciling Direct Benchmark Estimates and Time Series Projections", Journal of Economic History, 67, 315-349.

Broadberry, S.N. and Burhop, C. (2008), "Resolving the Anglo-German Industrial Productivity Puzzle: A Reply to Professor Ritschl”, Journal of Economic History, 68, 930-934.

Broadberry, S.N. and Ritschl, A. (1995), "Real Wages, Productivity, and Unemployment in Britain and Germany during the 1920s", Explorations in Economic History, 32, 327-349.

Bry, G. (1960), Wages in Germany 1871-1945, Princeton: Princeton University Press.

Buchheim, C. (1983), Deutsche Gewerbeexporte nach England in der zweiten Hälfte des 19. Jahrhunderts, Ostfildern: Scripta Mercaturae Verlag

Burhop, C. and Wolff, G.B. (2005), "A Compromise Estimate of German Net National Product, 1851-1913, and its Implications for Growth and the Business Cycle", Journal of Economic History, 65, 613-657.

Chapman, A.L. (1953), Wages and Salaries in the United Kingdom, 1920-1938, Cambridge: Cambridge University Press.

Clark, G. (2005), "The Condition of the Working Class in England, 1209-2004”, Journal of Political Economy, 113, 1307-1340.

Cole, G.D.H. and Postgate, R. (1987), The Common People, 1746-1946, (fourth edition), London: Methuen.

Davies, M.F. (1909), Life in an English Village: An Economic and Historical Survey of the Parish of Corsley in Wiltshire, London: Unwin.

Desai, A. V. (1968), Real Wages in Germany 1871-1913, Oxford: Clarendon Press.

Feinstein, C.H. (1972), National Income, Expenditure and Output of the United Kingdom, 18551965, Cambridge: Cambridge University Press.

Feinstein, C.H. (1990), "New Estimates of Average Earnings in the United Kingdom, 18801913", Economic History Review, 43, 595-632.

Feinstein, C.H. (1995), "Changes in Nominal Wages, the Cost of Living and Real Wages in the United Kingdom Over Two Centuries, 1780-1990", in Scholliers, P. and Zamagni, V. (eds.), Labour's Reward. Real Wages and Economic Change in $19^{\text {th }}$ - and $20^{\text {th }}$-Century Europe, Aldershot: Edward Elgar, 3-36 and 258-266.

Feinstein, C.H. (1998), "Pessimism Perpetuated: Real Wages and the Standard of Living in Britain during and after the Industrial Revolution", Journal of Economic History, 58, 625-658. 
Ford, P. (1934), Work and Wealth in a Modern Port: An Economic Survey of Southampton, London: Allen \& Unwin.

Fremdling,R., de Jong, H. and Timmer, M. (2007), "Censuses Compared: A New Benchmark for British and German Manufacturing 1935/36”, Journal of Economic History, 67, 350-378.

Frohmann, L. (2008), Poor Relief and Welfare in Germany from the Reformation to World War I, Cambridge: Cambridge University Press.

Gazeley, I. and Newell, A. (2007), "Poverty in Britain in 1904: An Early Social Survey Rediscovered”, IZA Discussion Paper No. 3046.

Hachtmann, R. (1988), "Lebenshaltungskosten und Reallöhne während des 'Dritten Reiches"”, Vierteljahrschrift für Sozial- und Wirtschaftsgeschichte, 75, 32-73.

Harris, J. (1972), Unemployment and Politics: A Study in English Social Policy, 1886-1914, Oxford: Clarendon.

Hennock, E.P. (2007), The Origin of the Welfare State in England and Germany, 1850-1914: Social Policies Compared, Cambridge: Cambridge University Press.

Hoffmann, W.G. (1965), Das Wachstum der deutschen Wirtschaft seit der Mitte des 19. Jahrhunderts, Berlin: Springer Verlag.

Hohls, R. (1995), “The Sectoral Structure of Earnings in Germany, 1885-1985”, in Scholliers, P. and Zamagni, V. (eds.), Labour's Reward. Real Wages and Economic Change in $19^{\text {th }}$-and 20 $0^{\text {th }}$-Century Europe, Aldershot: Edward Elgar, 37-60 and 210-230.

Holtfrerich, C.-L. (1984), “Zu höhe Löhne in der Weomarer Republik? Bemerkungen zur Borchardt-These", Geschichte und Gesellschaft, 10, 122-141.

Holtfrerich, C.-L. and Forstmann, W. (1983), “Zur Entwicklung der Einkommensdifferenzen in den ersten Jahrzehnten der deutschen Industrialisierung: Eine Auswertung der Eisenbahnstatistik", Historical Social Research, 8, 38-62.

Huberman, M. (2004), "Working Hours of the World Unite? New International Evidence of Worktime, 1870-1913”, Journal of Economic History, 64, 964-1001.

Huberman, M. and Minns, C. (2007), “The Times They are Not 'Changin': Days and Hours of Work in Old and New Worlds, 1870-2000”, Explorations in Economic History, 44, 538567.

Jacobs, A. and Richter, H. (1935), Die Grosshandelspreise in Deutschland von 1792 bis 1934, Berlin: Hanseatische Verlagsanstalt. 
Jones, D. Caradog (1934), The Social Survey of Merseyside, Liverpool: Liverpool University Press.

Kaiserliches Statistisches Amt (1909), Erhebung von Wirtschaftsrechnungen minderbemittelter Familien im Deutschen Reich, Berlin: Carl Heymann.

Khoudour-Castéras, D. (2008), “Welfare State and Labor Mobility: The Impact of Bismarck's Social Legislationon German Emigration before World War I", Journal of Economic History, 68, 211-243.

Kuczynski, J. (1937), Löhne und Ernährungskosten in Deutschland 1820 bis 1937, Libau.

Kuczynski, J. (1945), A Short History of Labour Conditions under Industrial Capitalism, Vol.3, Part 1, Germany, 1800 to the Present, London: Muller.

Kuczynski, J. (1947), Die Geschichte der Lage der Arbeiter in Deutschland von 1800 bis in die Gegenwart, Vol. I, 1880-1932, (3 ${ }^{\text {rd }}$ edition), Berlin.

Labuske, K. and Streb, J. (2008), "Technological Creativity and Cheap Labour? Explaining the Growing International Competitiveness of German Mechanical Engineering Before World War I", German Economic Review, 9: 65-86.

Linsley, C.A. and Linsley, C.L. (1993), "Booth, Rowntree and Llewellyn Smith: A Reassessment of Interwar Poverty", Economic History Review, 46: 88-104.

Lovell, J. (1977), British Trade Unions, 1875-1933, London: Macmillan.

Maddison, A. (2003), The World Economy: Historical Statistics, Paris: Organisation for Economic Co-operation and Development.

Mallet, B. (1913), British Budgets, 1887-88 to 1912-13, London: Macmillan.

Mitchell, B.R. (1988), British Historical Statistics, Cambridge: Cambridge University Press.

Müller, J.H. (1954), Nivellierung und Differenzierung der Arbeitseinkommen in Deutschland seit 1925, Berlin: Duncker \& Humblot.

O'Brien, P.K. and Prados de la Escosura, L. (1992), "Agricultural Productivity and European Industrialization, 1890-1980”, Economic History Review, 45, 514-536.

O’Rourke, K. (1997), “The European Grain Invasion, 1870-1913”, Journal of Economic History, $57,775-801$.

Owen, A.D.K. (1933), A Survey of the Standard of Living in Sheffield, Sheffield: Sheffield Social Survey Committee. 
Peters, L.L. (1989), "Managing Competition in German Coal, 1893-1913”, Journal of Economic History, 49, 419-433.

Petzina, D. (1987), "Arbeitslosigkeit und Sozialstaat”, in: Abelshauser, W. (ed.), Die Weimarer Republik als Wohlfahrtsstaat, Stuttgart: Steiner, 239-259.

Phelps Brown, E.H. and M.H. Browne (1968), A Century of Pay: The Course of Pay and Production in France, Germany, Sweden, the United Kingdom and the United States of America, 1860-1960, London: Macmillan.

Pierenkemper, T. (1983), "Die Einkommensentwicklung der Angestellten in Deutschland", Historical Social Research, 8, 69-92.

Pierenkemper, T. (1987), “The Standard of Living and Employment in Germany, 1850-1980: An Overview", Journal of European Economic History, 16, 51-73.

Prest, A.R. (1954), Consumers' Expenditure in the United Kingdom, 1900-1919, Cambridge: Cambridge University Press.

Reuter, H.G. (1980), "Verteilungs- und Umverteilungseffekte der Sozialversicherung im Kaiserreich", in: Blaich, F. (ed.), Staatliche Umverteilung in historischer Perspektive, Berlin: Duncker \& Humblot, 107-163

Ritschl, A. (1990), "Zu hohe Löhne in der Weimarer Republik? Eine Auseinandersetzung mit Holtfrerichs Berechnungen zur Lohnposition der Arbeiterschaft 1925-1932”, Geschichte und Gesellschaft, 16, 375-402.

Ritschl, A. (2008), "The Anglo-German Industrial Productivity Paradox, 1895-1938: A Restatement and a Possible Resolution”, Journal of Economic History, 68, 535-565.

Ritschl, A. and M. Spoerer (1995), "Das Bruttosozialprodukt in Deutschland nach den amtlichen Volkseinkommens- und Sozialproduktsstatistiken, 1901-1995”, Jahrbuch für Wirtschaftsgeschichte, 1997 / 2, 27-54.

Routh, G. (1960), Occupation And Pay in Great Britain, 1906-60, London: Macmillan.

Rowntree, B.S. (1902), Poverty: A Study of Town Life, London: Macmillan.

Rowntree, B.S. (1941), Poverty and Progress: A Second Social Survey of York, London: Longmans.

Samuelson, P.A. (1964), “Theoretical Notes on Trade Problems", Review of Economics and Statistics, 46, 145-54. 
Scholz, R. (1986), "Lohn und Beschäftigung als Indikatoren für die soziale Lage der Arbeiterschaft in der Inflation", in Feldman, G.D. and Ambrosius, G. (eds.), Die Anpassung an die Inflation, Berlin: de Gruyter.

Smith, H. Llewellyn (1931-1935), The New Survey of London Life and Labour, 9 volumes, London: King.

Statistisches Reichsamt (various years), Statistisches Jahrbuch für das Deutsche Reich, Berlin: Statistisches Reichsamt.

Steiner, A. (2007), "Zur Neuschätzung des Lebenshaltungskostenindex für die Vorkriegszeit des Nationalsozialismus", Jahrbuch für Wirtschaftsgeschichte, 2007/2, 129-152.

Stone, R. and Rowe, D.A. (1954), The Measurement of Consumers' Expenditure in the United Kingdom, 1920-1938, Volume I, Cambridge: Cambridge University Press.

Thane, P. (1996), Foundations of the Welfare State, (second edition), London: Longman.

Tout, H. (1938), The Standard of Living in Bristol, Bristol: Arrowsmith.

Webb, S.B. (1980), "Tariffs, Cartels, Technology, and Growth in the German Steel Industry, 1879 to 1914", Journal of Economic History, 40, 309-329

Webb, S.B. (1982), "Agricultural Protection in Wilhelmian Germany: Forging an Empire with Pork and Rye", Journal of Economic History, 42, 309-326.

Wiegand, E. (1982), "Zur historischen Entwicklung der Löhne und Lebenshaltungskosten in Deutschland", in Wiegand, E. and Zapf, W. (eds.), Wandel der Lebensbedingungen in Deutschland. Wohlfahrtsentwicklung seit der Industrialisierung, Frankfurt/Main: Campus, 69-153.

Williams, E. (1896), Made in Germany, London: Heinemann.

Williamson, J.G. (1995), “The Evolution of Global Labor Markets Since 1830: Background Evidence and Hypotheses", Explorations in Economic History, 32, 141-196. 


\section{Preprints 2009}

Andreas Glöckner / Sara D. Hodges: Parallel Constraint Satisfaction in Memory-Based Decisions. 2009/17.

Niels Petersen: Review Essay - How Rational is International Law? 2009/16.

Felix Bierbrauer: On the legitimacy of coercion for the financing of public goods. 2009/15.

Feri / Irlenbusch / Sutter: Efficiency Gains from Team-Based Coordination - Large-Scale Experimental Evidence.2009/14.

Jos Jansen: On Competition and the Strategic Management of Intellectual Property in Oligopoly. 2009/13.

Martin Hellwig: Utilitarian Mechanism Design for an Excludable Public Good. 2009/12.

Philipp Weinschenk: Persistence of Monopoly and Research Specialization. 2009/11.

Nina Horstmann/Andrea Ahlgrimm/Andreas Glöckner: How Distinct are Intuition and Deliberation? An Eye-Tracking Analysis of Instruction-induced Decision Modes. 2009/10.

Thorsten Lübbers: Is Cartelisation Profitable? A Case Study of the Rhenish Westphalian Coal Syndicate, 1893-1913. $2009 / 9$.

Andreas Glöckner/Bernd Irlenbusch/Sebastian Kube/Andreas Nicklisch/Hans-Theo Normann: Leading with(out) Sacrifice?

A Public-Goods Experiment with a Super-Additive Player. 2009/8.

Carl Christian von Weizsäcker: Asymmetrie der Märkte und Wettbewerbsfreiheit. 2009/7.

Jos Jansen: Strategic Information Disclosure and Competition for an Imperfectly Protected Innovation. 2009/6.

forthcoming in: Journal of Industrial Economics

Niels Petersen: Abkehr von der internationalen Gemeinschaft? - Die aktuelle Rechtsprechung des US Supreme Court zur innerstaatlichen Wirkung von völkerrechtlichen Verträgen. 2009/5.

Johannes Rincke / Christian Traxler: Deterrence Through Word of Mouth. 2009/4.

Christian Traxler / Joachim Winter: Survey Evidence on Conditional Norm Enforcement. 2009/3.

Britta Herbig / Andreas Glöckner: Experts and Decision Making: First Steps Towards a Unifying Theory of Decision Making in Novices, Intermediates and Experts. 2009/2.

Martin Beckenkamp: Environmental dilemmas revisited: structural consequences from the angle of institutional ergonomics. 2009/1.

\section{Preprints 2008}

Carsten Burhop: The Underpricing of Initial Public Offerings in Imperial Germany, 1870-1896. 2008/46.

Martin Hellwig: A Note on Deaton's Theorem on the Undesirability of Nonuniform Excise Taxation. 2008/45.

Martin Hellwig: Zur Problematik staatlicher Beschränkungen der Beteiligung und der Einflussnahme von Investoren bei großen Unternehmen. 2008/44.

published in: Zeitschrift für das gesamte Handelsrecht und Wirtschaftsrecht 172 (2008), 768 - 787

Martin Hellwig: Systemic Risk in the Financial Sector: An Analysis of the Subprime-Mortgage Financial Crisis. 2008/43.

Andreas Glöckner / Ann-Katrin Herbold: Information Processing in Decisions under Risk: Evidence for Compensatory Strategies based on Automatic Processes. 2008/42.

Jörn Lüdemann / Stefan Magen: Effizienz statt Gerechtigkeit? 2008/41.

Christoph Engel: Die Bedeutung der Verhaltensökonomie für das Kartellrecht. 2008/40.

Felix Bierbrauer: A unified approach to the revelation of public goods preferences and to optimal income taxation. 2008/39.

Carsten Burhop / Thorsten Lübbers: Incentives and Innovation? R\&D Management in Germany's High-Tech Industries During the Second Industrial Revolution. 2008/38. 
Andreas Nicklisch / Tobias Salz: Reciprocity and status in a virtual field experiment. 2008/37.

Andreas Glöckner / Christoph Engel: Can We Trust Intuitive Jurors? An Experimental Analysis. 2008/36.

Jörn Lüdemann: Wettbewerb und Regulierung in der Telekommunikation. Das Telekommunikationsrecht vor den Herausforderungen dynamischer Märkte. 2008/35.

published in: Jörn Lüdemann (Hrsg.), Telekommunikation, Energie, Eisenbahn - Welche Regulierung brauchen die Netzwirtschaften? Tübingen (Mohr Siebeck) 2008, S. 69-99

Martin Beckenkamp: Playing strategically against nature? - Decisions viewed from a game-theoretic frame. 2008/34.

Christoph Engel: Preponderance of the Evidence versus Intime Conviction. A Behavioural Perspective on a Conflict between American and Continental European Law? 2008/33.

Kristoffel Grechenig: Schadenersatz bei Verletzung von $§ 14$ WpHG? Insiderhandel mit positiver und negativer Information. 2008/32.

Felix Bierbrauer: Optimal Income Taxation, Public Goods Provision and Robust Mechanism Design. 2008/31.

Hans-Theo Normann: Vertical Integration, Raising Rivals’ Costs and Upstream Collusion. 2008/30.

forthcoming in: European Economic Review

Martin Hellwig: Competition Policy and Sector-Specific Regulation for Network Industries. 2008/29.

forthcoming in: X. Vives (ed.), "Competition Policy in the EU: Fifty Years on from the Treaty of Rome" Oxford University Press.

Niels Petersen: Rational Choice or Deliberation? - Customary International Law between Coordination and Constitutionalization. 2008/28.

forthcoming in: Journal of Institutional and Theoretical Economics 165 (2009)

Stephen Broadberry / Carsten Burhop: Resolving the Anglo-German Industrial Productivity Puzzle, 1895-1935:

A Response to Professor Ritschl. 2008/27.

forthcoming in: Journal of Economic History

Niels Petersen: Demokratie und Grundgesetz - Veränderungen des Demokratieprinzips in Art. 20 Abs. 2 GG angesichts der Herausforderungen moderner Staatlichkeit. 2008/26.

forthcoming: Jahrbuch des öffentlichen Rechts der Gegenwart 57 (2009)

Andreas Nicklisch: Semi-collusive advertising and pricing in experimental duopolies. 2008/25.

Andreas Nicklisch: Inequity Aversion, Reciprocity, and Appropriateness in the Ultimatum-Revenge Game. 2008/24.

Christoph Engel: The Behaviour of Corporate Actors. A Survey of the Empirical Literature. 2008/23.

Emanuel Vahid Towfigh: Komplexität und Normenklarheit - oder: Gesetze sind für Juristen gemacht. 2008/22.

Christian Traxler / Andreas Reutter: Apportionment, Fiscal Equalization and Decentralized Tax Enforcement. 2008/21.

Christoph Engel, REITs ante portas. Die Anpassung des deutschen Rechts an institutionelle Investoren in den Grundstücks- und Mietmärkten. 2008/20.

forthcoming in: Juristenzeitung

Christoph Engel, Ernst-Joachim Mestmäcker. 2008/19.

forthcoming in: Stefan Grundmann / Karl Riesenhuber (eds.): Deutschsprachige Zivilrechtslehrer des 20. Jahrhunderts in Berichten ihrer Schüler, Band 2, Berlin (De Gruyter) 